\title{
The Total Track Inspection
}

\author{
Sakdirat Kaewunruen*, Mohd Haniff Bin Osman and Panrawee Rungskunroch \\ Department of Civil Engineering, School of Engineering, University of Birmingham, Birmingham, United Kingdom
}

Operations of railway business have always placed "safety" as the first priority. Managing "public safety" requires integral risk monitoring and management. The risk monitoring for rail infrastructure management relies on accurate health monitoring and integrated track inspection. Health monitoring of all rail assets have given rise to "Big Data," which have been derived and recorded from on-board monitoring and on-track inspections of both fixed and mobile assets. In this paper, the safety-critical inspections of fixed assets or railway infrastructures have be emphasized in order to obtain the integral insights into track defects, irregularities and deterioration of track geometry and components. This paper highlights the systems-based integration framework of on-board and on-site inspection data for railway track integrity assurance under uncertain settings. The risks and consequences of extreme climates have been considered in order to improve

OPEN ACCESS

Edited by:

Sanjay Shrawan Nimbalkar University of Technology Sydney,

Australia

Reviewed by:

Sujit Kumar Dash, Indian Institute of Technology Kharagpur, India Yifei Sun

Hohai University, China

*Correspondence:

Sakdirat Kaewunruen

s.kaewunruen@bham.ac.uk

Specialty section:

This article was submitted to Transportation and Transit Systems,

a section of the journal

Frontiers in Built Environment

Received: 27 November 2018 Accepted: 17 December 2018

Published: 09 January 2019

Citation:

Kaewunruen S, Osman MHB and Rungskunroch P (2019) The Total Track Inspection.

Front. Built Environ. 4:84. doi: 10.3389/fbuil.2018.00084 adaptiveness, agility, and readiness of the systems-based framework of the total track inspection activities that could underpin and assure track infrastructure integrity and resilience. New challenges in observational field data have been highlighted as the evidences for the necessity for the adaptive systems-based framework of the total track inspection.

Keywords: track inspection, total inspection, systems integration, on-board monitoring, on-track inspection, track integrity assurance

\section{INTRODUCTION}

Track inspection has formed an integral part of railway operation and maintenance of a railway network (Esveld, 2001; Remennikov and Kaewunruen, 2008; Indraratna et al., 2011; Bin Osman et al., 2018). Creating added value from inspection data has been paid a special attention by many researchers around the world over the past three or four decades (Bin Osman and Kaewunruen, 2018a; Kaewunruen and Chiengson, 2018; Ngamkhanong et al., 2018b). However, the function or activities of track inspection are very complicated and rather non-linear. Most researchers specifically focus on a particular activity in the total track inspection framework (Esveld, 2001). Without an integrated framework, the interconnected risks are unmanageable, resulting in unplanned maintenance, corrective maintenance, even train delays, or eventually train derailments. Many lessons learnt by railway organizations and authorities have established stringent rules and policies around the track integrity assurance. Systems thinking approach has been adopted within the industry for decades, in order to enable systems and interconnected risk monitoring and management (Kaewunruen, 2017). Note that these lessons learnt are often kept secret or behind the scene within the rail industry, in order to avoid media attacks, impaired reputation or even public panicking. In reality, eliminating risk totally can cost the pubic exponentially since every track kilometer will be gold plated (or overly designed with very high redundancy). In fact 


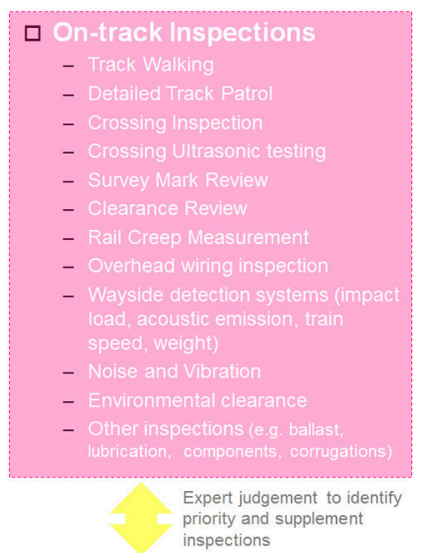

On-board Inspections

Engine Ride

Track Inspection Vehicle (Geometry)

Rail surface testing

Crossing Profiling

Rail wear investigation

Laser Clearance Review

Overhead wiring inspection (thermal

infrared)

- Ride comfort (Customer Experience)

Axle box acceleration and tractive

effort monitoring

- Acoustic Emissions

Pollution and others (e.g. slips, leaves,
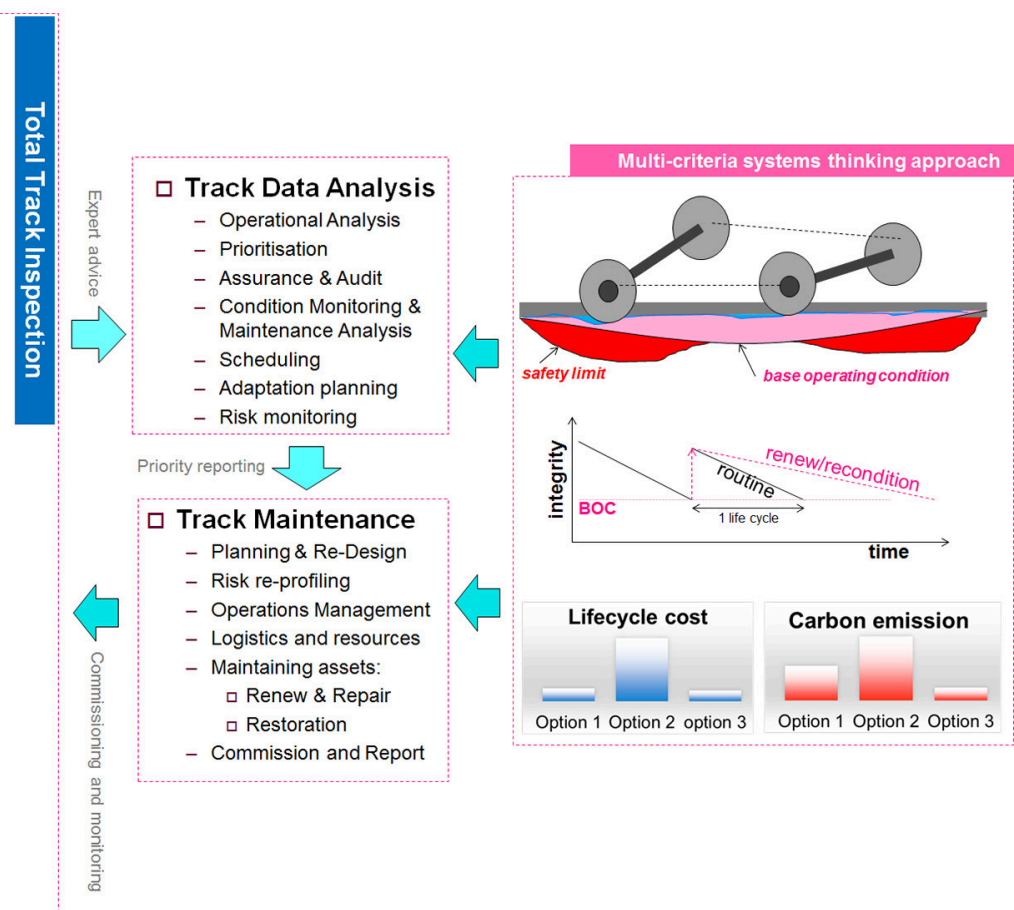

FIGURE 1 | Total track inspection.

there are uncertainties and unknowns that are often invisible (for example, sinkhole, Earthquakes, vandalisms, terrorists, extreme climate, etc.) (Kaewunruen and Remennikov, 2008a; Kaewunruen et al., 2015, 2016; Sa'adin et al., 2016; Azzoug and Kaewunruen, 2017; Ngamkhanong et al., 2017; Setsobhonkul et al., 2017). The railway industry has thus developed the integrated total risk management and monitoring framework to manage assets (both fixed and mobile). The risk monitoring aspect will require experienced staff with expertise, especially with local knowledge. This paper is thus the first to present the total track inspection, which is an essential part of railway systems risk management (e.g., ISO 55000). Railway tracks, or "fixed asset," are continuous, safety-critical elements, and inevitably require "track integrity assurance," which assembles the coordinated activities for any track engineering department to identify and underpin safety and reliability prior to realizing values from the track assets. Often, the main stakeholders of the track integrity assurance are the maintenance team (who can rank the priorities), rail regulator (who can evaluate overall safety and reliability), emergency team (who can manage resilience, adaptation and crisis), and rail authority and government (who can assign budget).

\section{FIXED ASSETS AND TOTAL INSPECTION}

Railway assets could include a wide variety of sub-systems components such as railway tracks, special trackwork (turnouts, switches and crossings, yards, sidings, loops), signals, controls and communications systems, overhead wiring structures, platforms and stations, bridges and viaducts, tunnels, airspace development (e.g., shopping centers, busway, hotels, etc.), billboards, buildings, and other infrastructure components. To assure reliable and safe operations, these assets require regular inspections and maintenance. Critical track assets are the infrastructure components interfaced with rolling stocks or trains. The critical track assets are track components (i.e., rail, lubrication systems, fastening systems, sleepers, ballast, and formation/foundation), electrification (i.e., overhead line equipment), track support structures (i.e., bridges and viaducts), and interface infrastructure (i.e., platforms). Figure 1 illustrates the critical track assets, track inspection activities, data analytic and decision making process (Kaewunruen and Remennikov, 2006, 2008b; Kaewunruen, 2014, 2018; Kaewunruen and Ishida, 2016; Tuler and Kaewunruen, 2017; Ngamkhanong et al., 2018a). Total track inspection activities are grouped into on-board monitoring (using a train and equipped sensors) and on-site inspections (through detailed equipment and human resources). These activities aim to target railway track defects, which can be classified into two main categories: track geometry defects and track component defects. These defects are caused by the deterioration of the conditions of track components over a longer period of time (e.g., 1 or 2 years), relatively to a train passage (over 30$60 \mathrm{~s})$. 
In particular, geometry defects result from the deterioration or failure of the track support system, while the component deflects are caused by the deterioration or failure of individual track components. Without appropriate inspection and maintenance, geometry defects will cause passenger discomfort, rough ride, increased dynamic and impact loads on track components, incorrect rail adjustment on curves, incorrect track centers and fouled clearances, and eventually a train derailment by altered wheel load distribution (Kaewunruen et al., 2017, 2018b). On the other hand, the component defects tend to cause more severe effects such as infrastructure damages, large settlements, highintensity impact loads, mud pumping, and so on, which can often lead to detrimental train derailments especially when the track is exposed to uncertain environments (Bin Osman and Kaewunruen, 2018b; Dindar et al., 2018; Kaewunruen et al., 2018a).

\section{CONCLUSION}

The total track inspection has been visualized in this mini review paper to provide a better insight into integrated risk assurance for railway tracks. It is essential to map out the total track inspection activities in order to assure that the track condition can be thoroughly assessed for either preventative or corrective track maintenance. This paper highlights the total inspection activities and their interconnectedness in order to help track engineers and researchers visualize the importance of each task.

\section{REFERENCES}

Azzoug, A., and Kaewunruen, S. (2017). RideComfort: a development of crowdsourcing smartphones in measuring train ride quality. Front. Built Environ. 3:3. doi: 10.3389/fbuil.2017.00003

Bin Osman, M. H., and Kaewunruen, S. (2018a). "Creating value added for railway track inspection," in Proceedings of the 29th Nordic Seminar on Railway Technology (Gothenburg), 46.

Bin Osman, M. H., and Kaewunruen, S. (2018b). Uncertainty propagation assessment in railway-track degradation model using bayes linear theory. J. Transport. Eng. A Syst. 144:04018026. doi: 10.1061/JTEPBS.0000146

Bin Osman, M. H., Kaewunruen, S., and Jack, A. (2018). Optimisation of schedules for the inspection of railway tracks. Proc. IMechE F J. Rail Rapid Transit 232, 1577-1587. doi: 10.1177/0954409717721634

Dindar, S., Kaewunruen, S., An, M., and Sussman, J. M. (2018). Bayesian Network-based probability analysis of train derailments caused by various extreme weather patterns on railway turnouts. Saf. Sci. 110, 20-30. doi: 10.1016/j.ssci.2017.12.028

Esveld, C. (2001). Modern Railway Track. Zaltbommel: MRT Press.

Indraratna, B., Rujikiatkamjorn, C., and Salim, W. (2011). Advanced Rail Geotechnology - Ballasted Track. London: CRC Press

Kaewunruen, S. (2014). Monitoring in-service performance of fibre-reinforced foamed urethane sleepers/bearers in railway urban turnout systems. Case Stud. Nondestruct. Test. Eval. 1, 19-24. doi: 10.1016/j.csndt.2014. 03.004

Kaewunruen, S. (2017). Underpinning systems thinking in railway engineering education. Austral. J. Eng. Educ. 22, 107-116. doi: 10.1080/22054952.2018.1440481

Kaewunruen, S. (2018). Monitoring of rail corrugation growth on sharp curves for track maintenance prioritization. Int. J. Acoustic. Vib. 23, 35-43. doi: 10.20855/ijav.2018.23.11078
Since most recent research focusses only on track geometry deterioration, the goal of this mini review is to encourage more research into the total track inspection, which will enhance the resilience of railway track systems facing natural and man-made uncertainties.

\section{AUTHOR CONTRIBUTIONS}

SK, MO, and PR conceptualized, reviewed, and wrote the mini review.

\section{FUNDING}

The publishing costs have been sponsored by the University of Birmingham Library's Open Access Fund.

\section{ACKNOWLEDGMENTS}

SK wishes to acknowledge the Australian Academy of Sciences and Japan Society for Promotion of Science for his JSPS Invitation Research Fellowship (Long-term), Grant No L15701. The authors would like to thank European Commission for H2020-MSCA-RISE Project No. 691135 RISEN: Rail Infrastructure Systems Engineering Network, which enables a global research network that tackles the grand challenge in railway infrastructure resilience and advanced sensing under extreme conditions (www.risen2rail.eu).
Kaewunruen, S., Aikawa, A., and Remennikov, A. M. (2017). Vibration attenuation at rail joints through under sleeper pads. Proc. Eng. 189, 193-198. doi: 10.1016/j.proeng.2017.05.031

Kaewunruen, S., and Chiengson, C. (2018). Railway track inspection and maintenance priorities due to dynamic coupling effects of dipped rails and differential track settlements, Eng. Fail. Anal. 193, 157-171. doi: 10.1016/j.engfailanal.2018.07.009

Kaewunruen, S., and Ishida, M. (2016). In situ monitoring of rail squats in three dimensions using ultrasonic technique. Exp. Tech. 40, 1179-1185. doi: 10.1007/s40799-016-0124-7

Kaewunruen, S., Lewandrowski, T., and Chamniprasart, K. (2018a). Dynamic responses of interspersed railway tracks to moving train loads. Int. J. Struct. Stabil. Dyn. 18:1850011. doi: 10.1142/S02194554185 00116

Kaewunruen, S., Lopes, L. M. C., and Papaelias, M. P. (2018b). Georisks in railway systems under climate uncertainties by different types of sleeper/crosstie materials. Lowland Technol. Int. 20, 67-76.

Kaewunruen, S., and Remennikov, A. M. (2006). "Nonlinear finite element modelling of railway prestressed concrete sleeper," in Proceedings of the 10th East Asia-Pacific Conference on Structural Engineering and Construction (Bangkok), 323-328.

Kaewunruen, S., and Remennikov, A. M. (2008a). An alternative rail pad tester for measuring dynamic properties of rail pads under large preloads. Exp. Mech. 48, 55-64. doi: 10.1007/s11340-007-9059-3

Kaewunruen, S., and Remennikov, A. M. (2008b). Experimental simulation of the railway ballast by resilient materials and its verification by modal testing, Exp. Tech. 32, 29-35. doi: 10.1111/j.1747-1567.2007. 00298.x

Kaewunruen, S., Sussman, J. M., and Einstein, H. H. (2015). Strategic framework to achieve carbon-efficient construction and maintenance of 
railway infrastructure systems. Front. Environ. Sci. 3:6. doi: 10.3389/fenvs.2015. 00006

Kaewunruen, S., Sussman, J. M., and Matsumoto, A. (2016). Grand challenges in transportation and transit systems. Front. Built Environ. 2:4. doi: 10.3389/fbuil.2016.00004

Ngamkhanong, C., Kaewunruen, S., and Baniotopoulos, C. (2017). A review on modelling and monitoring of railway ballast. Struct. Monitor. Maintenance 4, 195-220. doi: 10.12989/smm.2017.4.3.195

Ngamkhanong, C., Kaewunruen, S., Calçada, R., and Martin, R. (2018a). "Condition monitoring of overhead line equipment (OHLE) structures using ground-bourne vibrations from train passages," in Advances and Challenges in Structural Engineering. GeoMEast 2018. Sustainable Civil Infrastructures, eds $\mathrm{H}$. Rodrigues and A. Elnashai (Cham: Springer). doi: 10.1007/978-3-030-01932-7_2

Ngamkhanong, C., Kaewunruen, S., and Costa, B. J. A. (2018b). State-ofthe-art review of railway track resilience monitoring. Infrastructures 3:3. doi: 10.3390/infrastructures 3010003

Remennikov, A. M., and Kaewunruen, S. (2008). A review of loading conditions for railway track structures due to train and track vertical interaction. Struct. Control Health Monitor. 15, 207-234. doi: 10.1002/ stc. 227
Sa’adin, S. L. B., Kaewunruen, S., and Jaroszweski, D. (2016). Operational readiness for climate change of Malaysia high-speed rail. Proc. Inst. Civ. Eng. Transport 169, 308-320. doi: 10.1680/jtran.16.00031

Setsobhonkul, S., Kaewunruen, S., and Sussman, J. M. (2017). Lifecycle assessments of railway bridge transitions exposed to extreme climate events. Front. Built Environ. 3:35. doi: 10.3389/fbuil.2017.00035

Tuler, M. V., and Kaewunruen, S. (2017). Life cycle analysis of mitigation methodologies for railway rolling noise and groundbourne vibration. $J$. Environ. Manage. 191, 75-82. doi: 10.1016/j.jenvman.2016.12.075

Conflict of Interest Statement: The authors declare that the research was conducted in the absence of any commercial or financial relationships that could be construed as a potential conflict of interest.

Copyright $\odot 2019$ Kaewunruen, Osman and Rungskunroch. This is an open-access article distributed under the terms of the Creative Commons Attribution License (CC $B Y)$. The use, distribution or reproduction in other forums is permitted, provided the original author(s) and the copyright owner(s) are credited and that the original publication in this journal is cited, in accordance with accepted academic practice. No use, distribution or reproduction is permitted which does not comply with these terms. 